\title{
RIVERBANK SETTLEMENT AND HUMANITARIAN ARCHITECTURE, THE CASE OF MANGUNWIJAYA'S DWELLINGS AND 25 YEARS AFTER, CODE RIVER, YOGYAKARTA, INDONESIA
}

\author{
Noor Cholis IDHAM ${ }^{\star}$ \\ Department of Architecture, Universitas Islam Indonesia, \\ Jl. Kaliurang km. 14.4, 55584, Yogyakarta, Indonesia
}

Received 03 July 2018; accepted 03 December 2018

\begin{abstract}
Code riverbank has drawn worldwide attention since 90's when Architect Mangunwijaya involved in the dispute of urban riverside settlement in Yogyakarta. Struggling for the slum between the municipality and the dwellers gradually dwindled, and one of most significant causes was his humanitarian dwelling self-help scheme on Kampung Code. The project, which was later recognized by Aga Khan Award for Architecture in 1992, was not only purposed for reducing the tension but also promoting appropriate social order by considering the natural environment vulnerability. One of the poorest and most crook riverbank zones of the city had transformed to be a better environment with positive atmosphere afterward. Unfortunately, the project was hardly followed by other dwelling construction either in the site or other parts of the bank. This paper studies how the architecture could cure the social problems as well as resolve the environmental challenges and its sustainability. The social approaches done by Mangunwijaya and how he captured the high-risk of riverbank nature to the dwelling concepts were accessed. The results indicate that in spite of the riverside's slum controversies, the architecture should be considered as a remedy both for social and natural problems.
\end{abstract}

Keywords: riverbank settlement, slum architecture, building safety, disaster risk reduction, contextual structure, Kampung Code.

\section{Introduction}

Code, spelled as Cho-de, is one of three main rivers flow in Yogyakarta Province starting from Mount Merapi and ending in the Indian Ocean. The river which was chosen as the primary consideration for the site of Yogyakarta sultanate capital drifts in the middle of the city and stretch around $60 \mathrm{~km}$ from north to south passing three administrative districts of Sleman, the City of Yogyakarta, and Bantul. Although the river is not wide enough, only about 25 meters span, it was essential to connect the mountain and the sea and brings not only water but also volcanic materials such as stones and sands which accumulate in the bottom make the stream shallower all the time. The municipality keeps the river depth by excavating periodically the sediment settled in the bottom of the river to avoid overflowing water. However, high-intensive tropical rains cause the river and its bank prone to flooding both from the upstream and the higher land on the sides. Flood as result of increasing water level beyond its capacity is occasionally threatening the dwellers by draining millions of meter cubic of volcanic materials troughs the river.
Moreover, Code is a vital river to the region since it streams not only through the city center, but also attracts many utilizations on its space since its history. Although it was cultivated intensively for vegetable plantation in its very fertile banks, because of its accessible location and the increasing urbanization, the banks have been occupied as settlement area with the most crowded shelters in the city. Spaces needed for water-stream overwhelmed with an inhabited area (see Figure 1). Although it is on the sloped bank under the Gondolayu Bridge with only around $3000 \mathrm{~m}^{2}$, the location is very strategic. It is just right the city's main street Sudirman and other most important places such as the three most prominent markets Kranggan, Terban, and Beringharjo; the central business district streets MalioboroMangkubumi; and the Tugu central train station. By 90's 35 households with about 70 people resided on the riverside behind the row of garages already built in the west side of Faridan M. Noto Street. The number of inhabitant as well as the household is then always swelling from about 70 (35) in 1992 to 168 (62) in 2001, 224 (73) in 2012, and 344 (97) in 2018, and has made the settlement progressively

${ }^{*}$ Corresponding author. E-mail: noor.idham@uii.ac.id 
overloaded. The settlement were occupied illegally without any environmental infrastructure as a characteristic of slum (UN-Habitat, 2016) or poor living condition outside the formal planning effort with negative impacts in many area of life (Friesen, Taubenböck, Wurm, \& Pelz, 2018). As the dwellings number is rapidly increasing; crime, disease, illiteracy, and unemployment are also rise up (Nisbett, 2017).

One of the most important issues is regarding to safety since it close to the river with distance only two meters or less. The possibility of overflowing water from the river reaches up to 30 meters (Sulistiyono, 2011). When the river over spilled in 2010, 70\% area was categorized as highest risk, and thousand people were affected with the least income was the most vulnerable from the disaster (Sagita \& Widiyanto, 2012; Setyaningrum \& Giyarsih, 2012). As a result, the flow of water in the peak of the rainy season or in case of flooding volcanic materials from Mount Merapi often over the boundary and swept away many dwellings along the river. Several houses were destructed, 898 in November 2010 and 1191 in March 2011, and the loss was reported in billions rupiah (Radja, 2011).

Considering the city landscape, natural, and social problems on the bank, the parliament has released province legislation of Perda No. 2 the year 2010 to rearrange and relocate the settlement. It was followed by Mayor of Yogyakarta Decree No. 393 the year 2014, which considers the Code settlement as highly deteriorate slum (Hutama, 2016). Since 2016, three low-budget rental apartments or Rusunawa: Jogoyudan, Cokrodirjan, and Jumiwahan were built to relocate the people. However, the flats only available $8.31 \%$ from housing demand in the area (Amalia, 2013). Vertical housing or Rumah Susun abbreviated as Rusun, seems not yet as the answer for urban housing problems in Indonesia particularly in Yogyakarta. The resettlement program is less succeeded compare to other countries because the budget that affects the number of the Rusun is insufficient, and the location is mostly far away from the evicted communities' original location and employment opportunities (Rolnik, 2014). Many vertical housing projects were even resulting complicated prob-

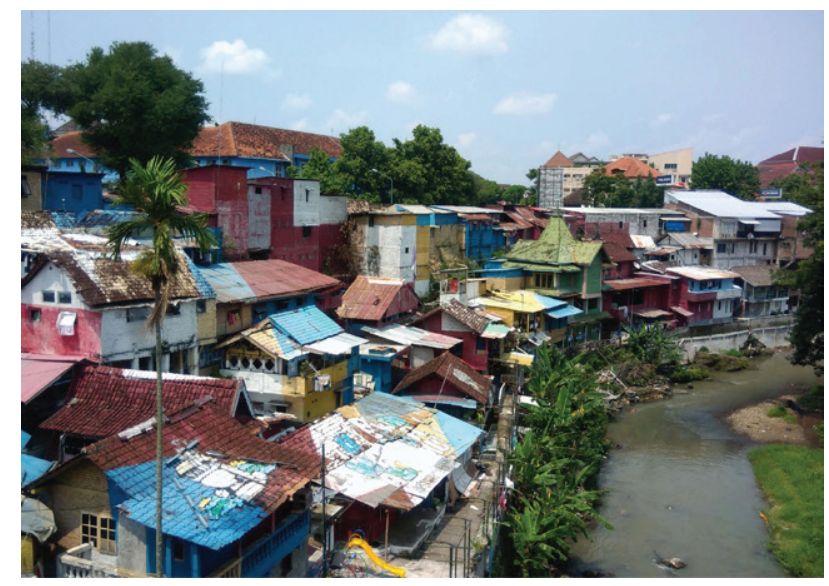

a) lems related to legal aspects and occupancy (Sudaryatmo, 2016). In case of Yogyakarta, though the three Rusun were built near the original kampung, most of the people still prefer to stay in the slum (Ayodiya, 2014). Although those three Rusun finally occupied by people, they have some problems related to social degradation and carelessness (Pratama, Rachmawati, \& Kunci, 2016).

Kampung Code, one of Code's riverbank settlements on the east bank of the northern part of the city, was one of the significant problems as well as very well-known solution for the humanitarian project as self-help dwelling program led by Mangunwijaya in 90's by unique architecture dealing with the social and environmental issues. Kampung (Indonesian/Malay) or kampong (Cambodian) was originally the term used for a waterfront settlement (Widodo, 2012) which lately has been adopted widely as kampong. Kampung in Indonesian cities is a residential part which is self-developed by the people to resolve their problems. The solution of the settlement problem by Mangunwijaya was acknowledged by the people as well as global community and the municipality which means guarantee the appropriateness of the project. The aim of this study are to rediscover the original proposal of Kampung Code project correlated to how the Architect cope with the slum's settlement problems as well as the threat of the nature and social considerations, and how those concepts affect the people life in the environment within 25 years after the project. The method used is by accessing the significant documents associated to the works such as the formal report of the Aga Khan Award (Al-Radi, 1992; Silas, 1992) to grasp the context and original concepts of the design solutions and field data gathering to discover the updated development of the settlement.

\section{Code riverbank and the beginning of the settlements problems}

The Illegal settlement became a crucial issue of Code riverbank dating back in 80 's when the initial problem appeared, followed by the struggling time, temporary final-

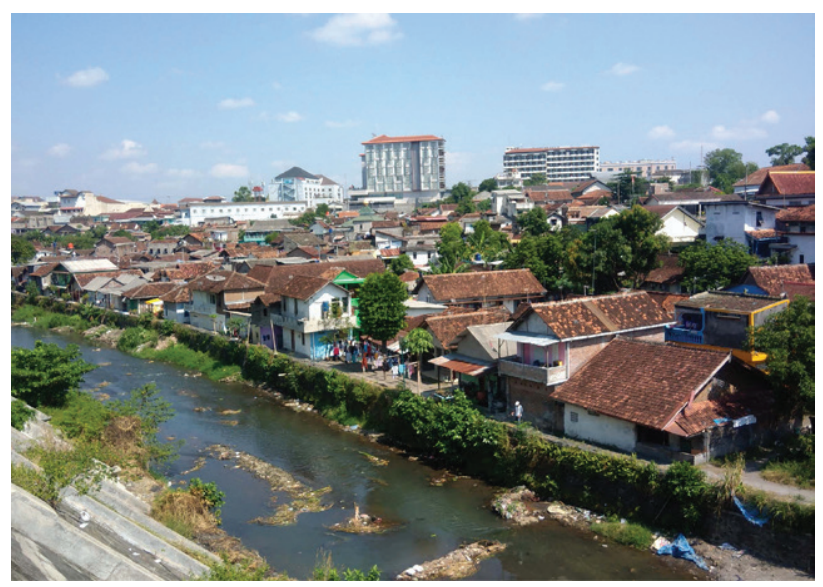

b)

Figure 1. Code riverbank settlements (a) Kampung Code and (b) Jogoyudan in 2018 
ized by settled periods, and its development. Each of the phases has its specific condition as follows:

The significant early settlement appeared in the 70's when many homeless began to occupy the bank illegally. They were lying under the bridges or constructing nonpermanent huts from any materials they could found such as cartoon boards and woven bamboo which were quickly swept away when the river overflows (Haryadi, 2014). Became occupied intensively, Kampung Jetisharjo in the Code's northern bank was the first kampong in the north part of the bank in 1981 with $0,66 \mathrm{~km}^{2}$ area (Ramdhon, 2018). The other parts of the bank began significantly occupied including Kampung Code. Unlike most slum's cases in the world such as in India or Egypt where the people occupying the land for their business (G. Ragheb, El-Shimy, \& A. Ragheb, 2016), the inhabitants were staying only for sleeping. They came to the city from rural and hinterland region to seek a job while waiting for harvesting time. They were only staying in the area mostly in the nighttime, but in the daytime, they were working in the markets and the streets as a seller, worker, street singer, bagger, pickpocket, burglar, prostitute, and others. As limiting agricultural landfill in the villages as well as increasing economic activities in the city, they started to living permanently in those illegal settlements or slums.

The slums began to disrupt the city's landscapes when the huts population increased dramatically and triggered the involvement of the municipality which decided to restrict the kampung in 1984. Code riverbank had been associated with the city's problem where most struggling appeared between the unfortunate settlers and the municipality (Haryadi, 2014). Crimes were high triggered by these very low-income people who were struggling for their life making the area as the most dangerous quarter of the city (Seftyono, 2012). Almost nobody dared to come in the zone, and the inhabitants were likely untouchable. For all those reasons, the Government of the Special Region of Yogyakarta supported by Gadjah Mada University decided to displace these settlements (Silas, 1992). An initial official regulation was issued by the Governor Decree 1985 for the settlement removal, and troubles then took place to raise up (Al-Radi, 1992). Removing the slums was the only option for the government to control the city's social and natural problems. The government was periodically eradicating the shelters by burning and dismissing the people, but they came back and directly reconstructed others as soon as the officers left.

The ongoing eviction, particularly in Kampung Code, was halted after Willi Prasetya, chief of the village together with Mangunwijaya, persuaded the government to postpone the execution of the Decree, and the settlement survived for a while (Al-Radi, 1992). The struggles had been decreased, and the people were continuing the riverbank occupation. However, deteriorating the environment was worsening. Thus the government was delivering some improvement programs on the settlement to support living appropriateness. Unfortunately, the plans less succeeded. For example, seven programs were launched from 1988 to
1994 but most of them failed because the programs were sporadic, lack of the people's participation, and without social leader involvement (Kumorotomo, Darwin, \& Faturochman, 1995). The housing complications appeared in two aspects: social and natural. Socially, the settlements provided the space for underclass, poor, and criminals as public enemy blamed for any law-abiding incident in the city (Seftyono, 2012). Naturally, the dwellings constructed in the bank responsible for water stream hindrance which causing a flood (Sagita \& Widiyanto, 2012; Sulistiyono, 2011). The huts were blocking water flow not only from the upstream but also from the upper bank.

\section{Mangunwijaya and his project on the riverbank Kampung Code}

Yusuf Bilyarta Mangunwijaya (1929-1999) known as Romo Mangun or Father Mangun is an architect, teacher, author, as well as a priest who dedicated most of his life to humanity. He is also known as the founding father of modern Indonesian architecture. Beside received Aga Khan Award for Architecture in 1992 for the Code project, he was also the recipient of The Ruth and Ralph Erskine Fellowship in 1995 for his commitment to the less privileged. The Code riverbank project is one of his monumental works which cured the social and natural problem in the bank and positioned him as a philanthropic architect who leads the society to have a more decent life. His principles of architecture as Wastu and Citra as a manifestation of body and soul has deepened the meaning of his architecture (Mangunwijaya, 1988). His work on the bank not only resolved a functional and physical problem but also containing a strategic mission behind as the architectural soul which directs to the humanitarian concepts.

In the middle of the struggling time in Kampung Code, Mangunwijaya came to the people in 1990 and made himself as the facilitator between them and the government. He intended to help the people and to solve the problems by proposing and constructing the humanitarian dwellings supported by the people. The priest led the people in the bank to work on a self-help dwelling program to have proper life by building flats and houses, a public hall, a workshop cabin, a homeless shelter, communal toilets, a library, playgrounds, and a cleaning place. He proposed to develop the settlement under the existing row of garages in the upper part of the bank with some open area was still left in lower part for green-open space and flooding space from the river (Figure 2). He also assisted the people to have a better life by finding a more appropriate job instead to be criminals (Haryadi, 2014). To understand the people and to get their trust, he was even staying in a dwelling among the people in the bank for almost six years and became the trusted elder in the society (Istanto, 1999). He was fully aware of responding the environmental and social problems with organize social resources and local knowledge due to vicinity to events (Miller \& Douglass, 2016). By working together with his companion including his colleagues and students, he proposed some indigenous 


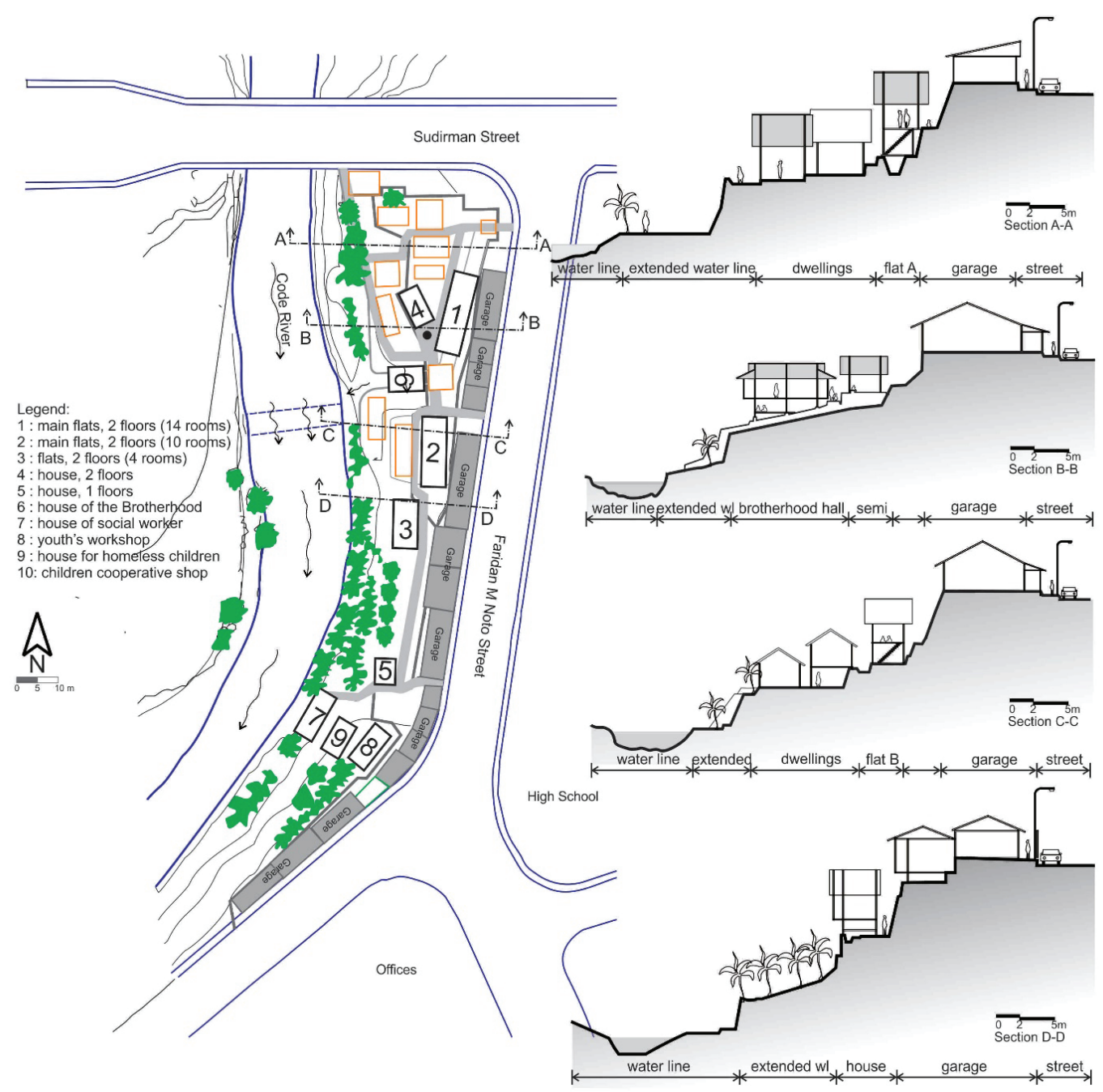

Figure 2. Code settlement by Mangunwijaya 1991 (redrawn and optimized from (Al-Radi, 1992))

dwellings which were aimed at resolving the settlement problems. With a limited budget and insignificant support both from the government and public, he finally succeeded to develop the settlement as seen as improvement program based on social approaches (Al-Radi, 1992; Cahyadi, 2007).

Mangunwijaya's intention was neither to cover the whole banks' area nor to construct the houses for all the people but giving such bridging program for living with appropriateness. The dwelling was even not aimed at permanent occupation considering the legal aspect of the land. The project was not more than humanitarian concern for the problem of the unfortunate dealing with such slanted sites as well as to the government. For the meantime, the settlement struggling was reduced, and the municipality restarted to assist and support the people by developing river terrace wall and shield wall from the overflowing water, constructing the sanitary system, giving electricity, and programming many work training under Kampung Improvement Program (KIP) (Al-Radi, 1992).

\section{Finding and discussion}

The success story of Mangunwijaya project has impacted on "legalization" of the bank settlement inside as well as outside the spot and turned the problems more complicated. By that progress, the occupation of the banks seems to be acknowledged although the houses are still residing in the restricted land for housing. A thousand dwellings were constructed in the whole of riverbanks, and the populations of the riverbank were increasing all time. Furthermore, the houses have overloaded all the banks with common permanent brick wall and reinforced concrete construction in double or even triple floors and left a narrow water stream which is far from an ideal river. The density of riverside settlements around the Code was more than 336 people per Hectare, and building density exceeded $80 \%$ of the land in 2010 (Lupiyanto, 2010). Recently, the concentration is increased to about 391 occupants per Hectare with the population is about 10.059 inhabitants from 2596 households which occupied almost all the banks about 25.69 hectares and the density is more than 90\% (Hutama, 
2016). The river that should have three zones: safety lines, ecological buffer zones, and water creek (Maryono, 2009), now is limited to have water flow only face to face with the residential area (see map on Figure 3 and Figure 4a). Decreasing space of the riverside and the explosion of the house population have ended the river beyond its capacity. Despite the social problems were might be overcome, the issue of the environment seems even worsening.

The fact that the struggle is always reappearing cyclically and most of the people were not following the Mangunwijaya's project in term of architecture, but they build the houses which no differences with others outside the bank, is predictable. Although decentralization including dealing to disaster is now better in Indonesia, the urban governance are tremendously still adverse (van Voorst, 2016). The slum upgrading program is actually even much earlier compare to any other country in the world with the KIP in Repelita program that launched in 1969 (Minnery et al., 2013). The Code project was considered and proven as the appropriate answer to resolve the settlement problems (Al-Radi, 1992), but it has been discontinued. The involvement of the authorities was still under expectation following the success of the project. Up to the moment, we still cannot find the similar dwelling concepts applied on the other parts of the riversides. Building's tradition seems affected more by the people rather than the newly-introduced idea despite the fact that it offers more appropriate social purposes and protection from the natural disasters. The mission and the aims of the concept were less successfully delivered to the people and other parties. For this reason, restudying on the dwelling concepts is essential not only for Mangunwijaya's dwelling revitalization purpose but also for more understanding the idea of the future's sustainable settlements.

\subsection{Code riverbank architecture as the social remedy}

Slum and crimes are just like the twin which cannot be separated. Most of the squatter dwelling have higher crime rate rather than other parts of a city. A slum is an unplanned residential area which is: (1) constructed and occupied illegally under private or government land, (2) congested without the involvement of the authority, and (3) considered as living below poverty line (Kumorotomo et al., 1995). In such places, social order is limited, and neighborhood infrastructure is absent. The expectation of the people which are the very low-income worker or even jobless is mere to achieve the fundamental needs. As architecture and morality is seen as integral and critical relationship (Fahey, 2017), crime seems the only way to struggle with when the needs fail to be obtained. Nevertheless, the slum is also offering perfect protection for criminals to escape from the law.

Residing on Code riverbanks, including Kampung Code, was only the option for the people despite the deficient quality environment or even below the limit of living properness in the 80 's. The inhabitants who were working and getting a small income from surrounding markets, shops, and streets would not easy to manage their business if they have to stay away from the city. As the banks' populations increased, the neighborhood was worsening to below level of appropriateness because of extreme poverty and squatter settlement (Al-Radi, 1992). The government with a limited budget in other side tend to prefer removing the people by settlement relocation which was unclear yet, and they rejected the program resulting in the intensive disputes on the bank.

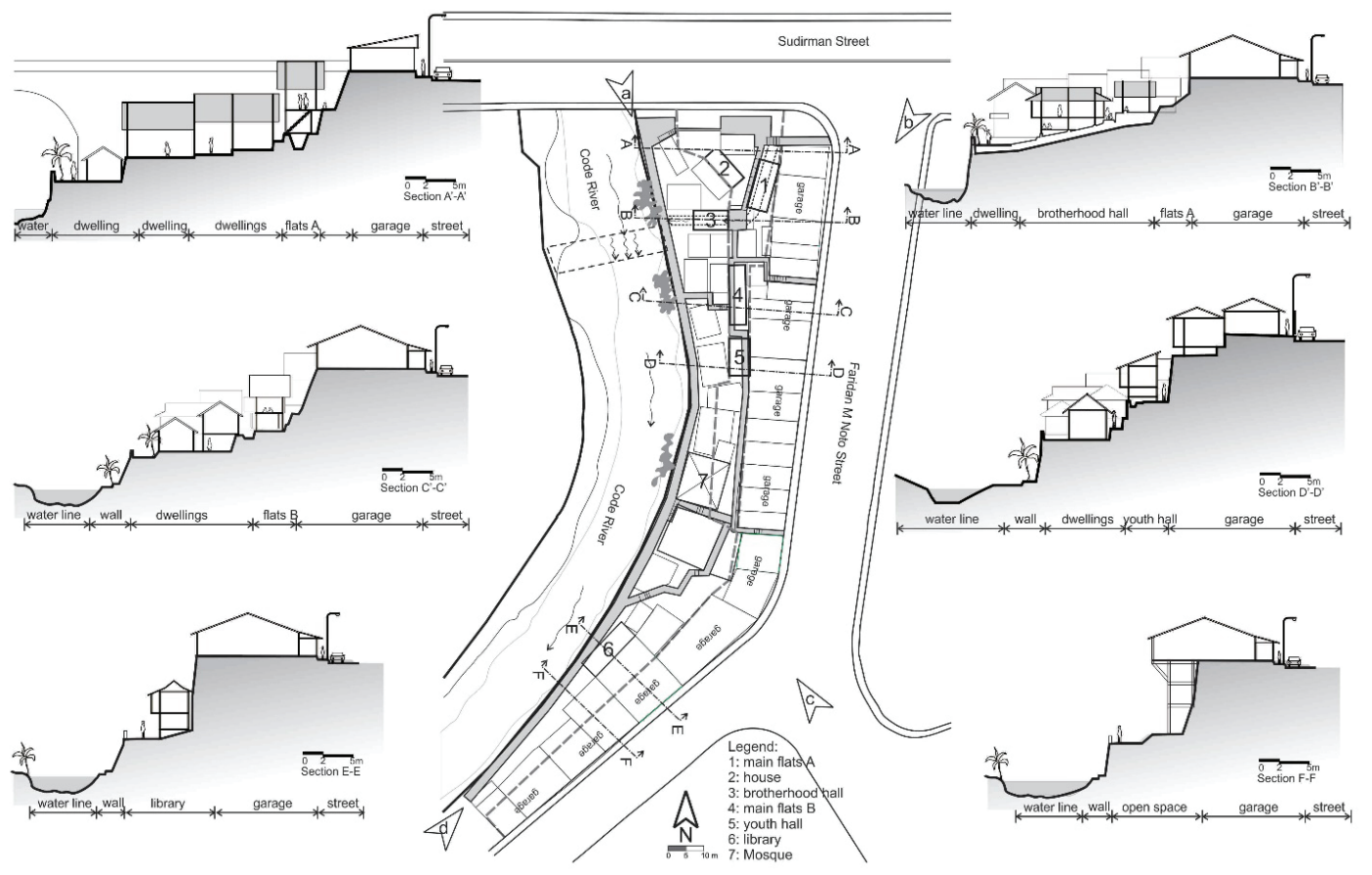

Figure 3. Settlement development in 2018 


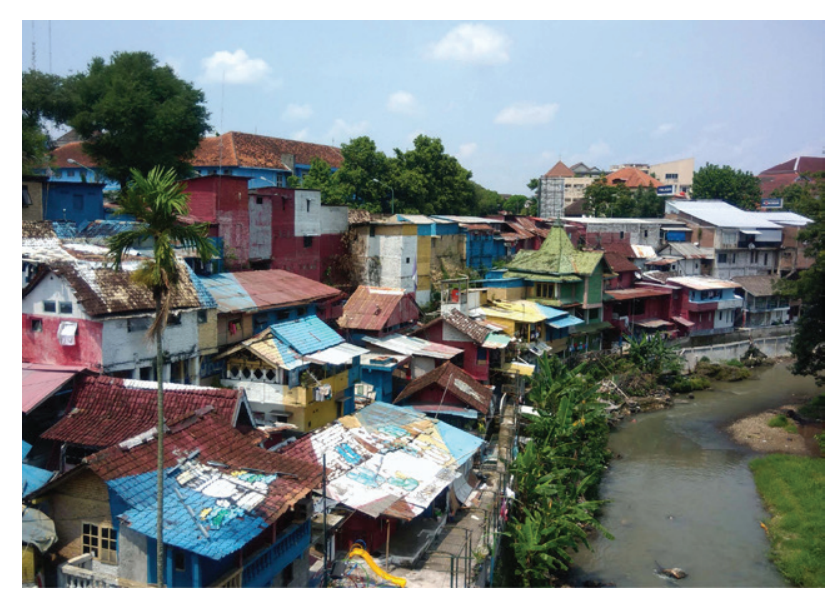

a)

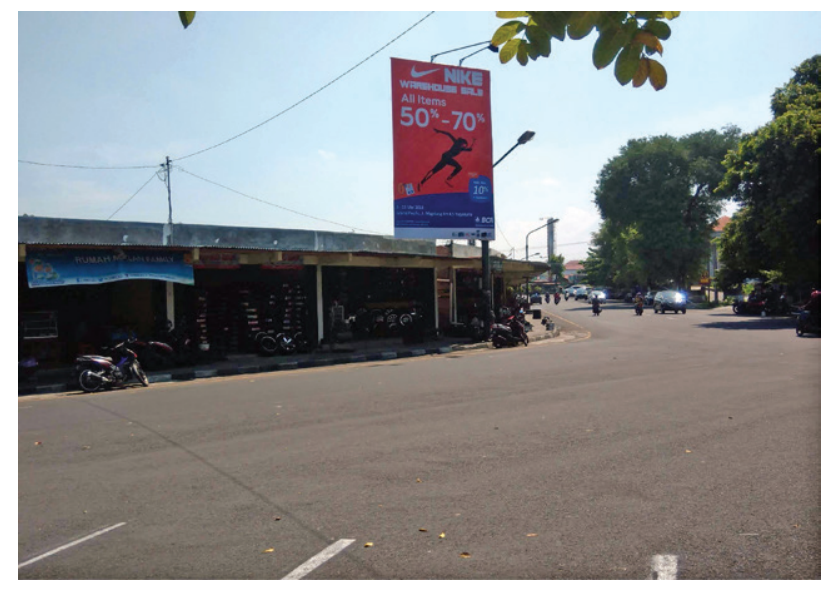

c)

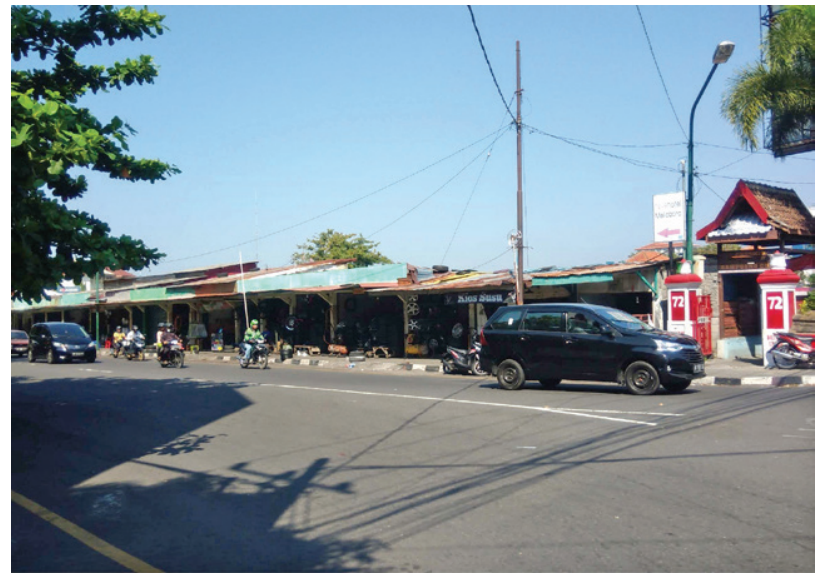

b)

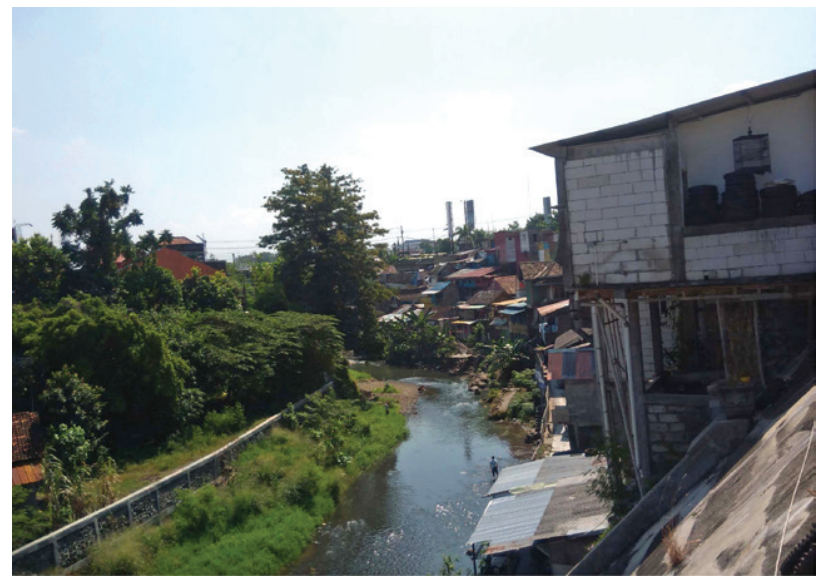

d)

Figure 4. Code views from (a) the bridge, (b) the Sudirman street, (c) Faridan M Noto street, and (d) the southern edge in 2018

The idea of "humanization" of the people by hearing their aspiration and understanding the problems was the method for the social problem remedy applied for the settlement. Mangunwijaya's project was not only aimed for making a suitable living environment but also for waiting for appropriate development from the government which was found as a political strategy for spanning the time and approaching softer solutions. Although the settlement was only built by few buildings in semi-permanent construction, its purpose was to give a model and to promote a proper community life by considering more on common spaces such as gathering hall, shared living rooms, library, toilets, and outdoor spaces in between. Well defined outdoor space and its physical quality will also boost the intensive communication among the people (Hutama, 2016). This kind of spaces was built to gather the people for knowing each other and for reconstructing the social order of the society. Village's administration has been formed, and the people were recognized and acknowledged by the municipality (Kresna, 2014).

People participation was also the other concern found in the settlement concepts to increase inhabitants' awareness of the environment. The orientation of the houses toward to the river is a way to promote readiness for the threat of the river as well as to keep carefulness of the river's cleanliness such as not littering with human's waste or dumping the trash on it. The ideas were useful, and the people responsiveness after the project has increased which is helping the neighborhood to be much better than before. Furthermore, crime was reduced by the social control that was achieved by construction of shared customs and norms. The collective efficacy enforces the public order even more influential than formal law (Fabusuyi, 2017). By such approaches, the environment solved the social problems with the role of architecture.

\subsection{The dwelling and natural synchronization}

Located in the riverbank, Mangunwijaya built the buildings on Kampung Code according to the physical condition of the river. Code River is one of the streams draining not only the high intense rainwater but also volcanic materials from Mount Merapi. The 2010 and 2011 eruptions brought millions meter-cubic of sands and stones from the volcanoes and destructed a thousand houses as mentioned before. Furthermore, since it passes through the middle of the area, high precipitation in the peak of 
rainy season surrounding the river has made Code as the most significant river drains the city. Using its land for any other purpose than watercourse is hazardous, and dwelling located in its bank is always prone to natural disaster.

However, since there was no other option for the people to find another place to stay, the dwellings should deal with nature accordingly. Mangunwijaya used an indigenous building design as a tool for synchronizing the environment. He tried best to accommodate the atmosphere related to Javanese village and its traditional houses by adopting the form with modification on the structural system which was synchronized to the higher vulnerability of the zone (see Figure 5). Unlike the Javanese houses that utilize the primary structure of four or eight central columns in the middle to bear the roof, the dwelling employs the central columns directly to support attic-like as enclosed space below the roof for the main room, and open space underneath for secondary functions. Because of land limitation, the multilevel floor structural system was applied to increase the room without sacrificing the building safety.

The elevated floor in stilts was reintroduced although it was not used anymore in Javanese traditional buildings. The high platform was originally for rice granary in South-east Asia region (Widodo, 2012) and it is technically the most suggested house's structural system for facing flood disaster (FEMA, 2014). Stilt house was reutilized to increase the dwelling's floor level to save the occupants from overflowing water both from the stream and the up- per bank in the rainy season while for accommodating a gathering in the sunny season. It was also aimed for keeping the soil open for water absorption, preventing insects and other wild animals from the creek, and repelling the river's humid air. Flats $\mathrm{A}$ and the brotherhood hall are the examples of this concept (Figures 5 and 6). All the buildings is constructed by wooden materials including bamboo both for structural system and finishing with corrugated or clay tiles on the roof. He was concerning that the houses are should be built non-permanently considering the status of the land.

Additionally, a wooden and bamboo structure which were affordable since the materials found effortlessly nearby was purposed for inhabitant safety and dwelling flexibility. As it was predicted for a high possibility to move out from the place anytime, the semi-permanent building with knockdown construction is the ideal option functionally, naturally, and politically. Open plan or soft story in a stilt house might be as a negative aspect considering the lateral forces (Murty, n.d.; Redmond \& Desroches, 2012). However, since the system in general is lightweight, flexible, and the building is not too high, the house is still safe. Many damaged cases in stilt house under an earthquake were cause by the additional wall which make the structure is not flexible anymore (Sastrawati, 2009). In general, the timber truss system on piles which forming the house on top and leaving the space under is a precaution to stronger lateral forces as the dwellings are situated in the earthquake-prone area. Because soft soil
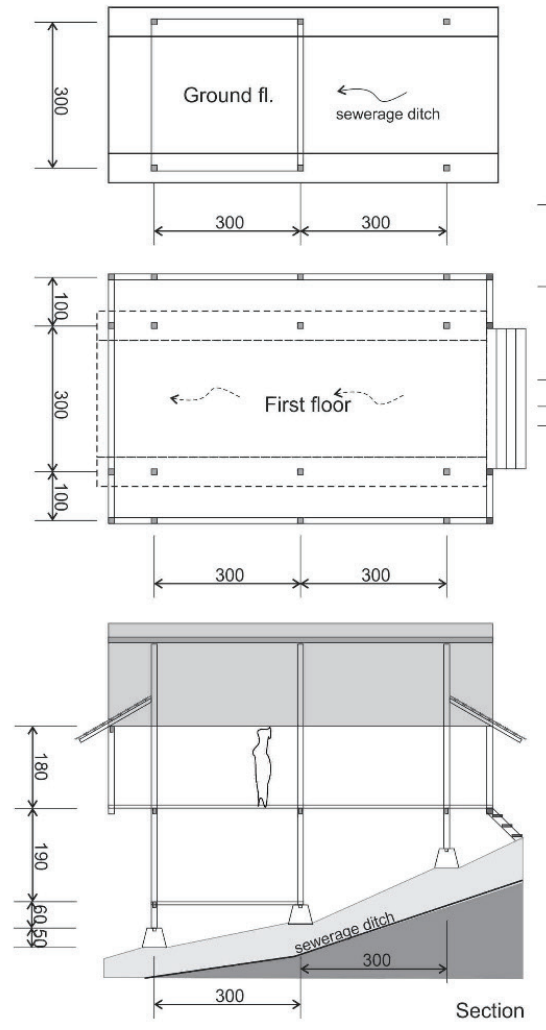
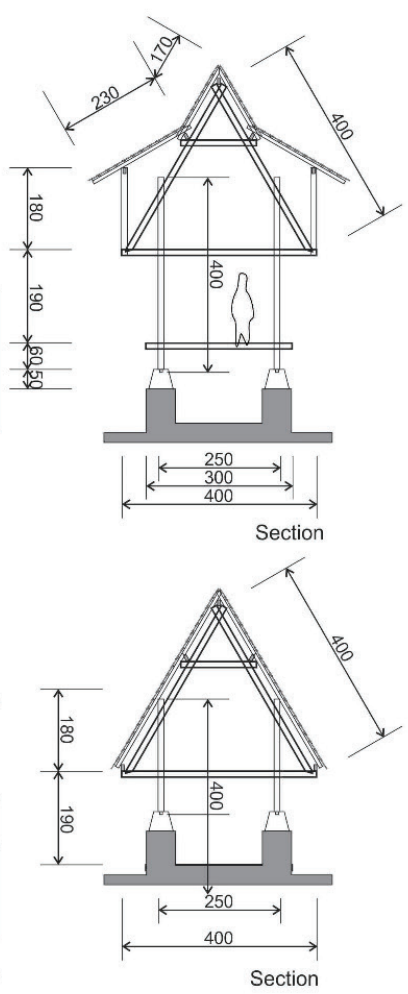

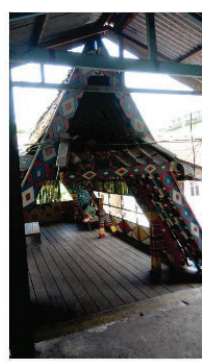

upper view

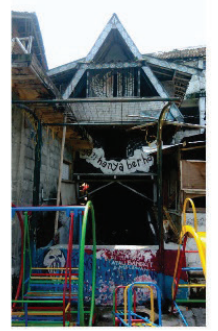

lower view

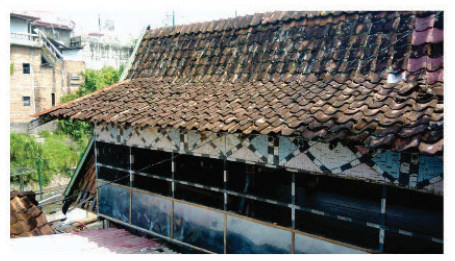

side view

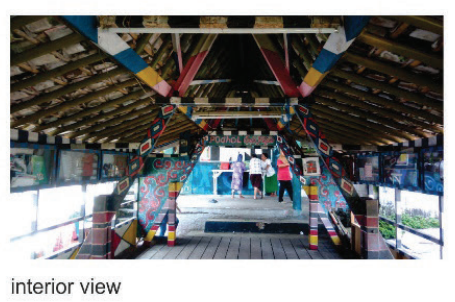

Figure 5. Brotherhood Hall drawings and pictures in 2018 


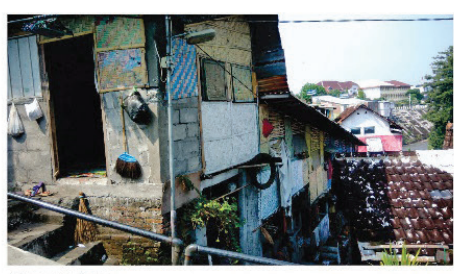

Upper view

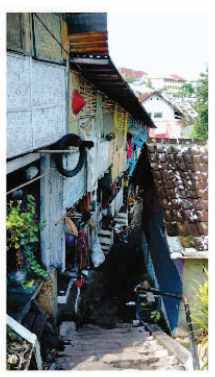

Alley view

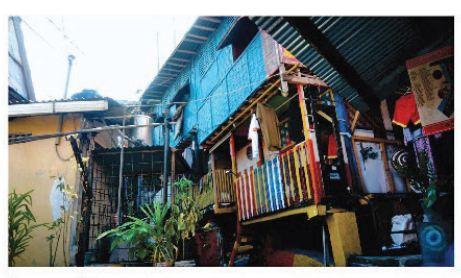

Lower view

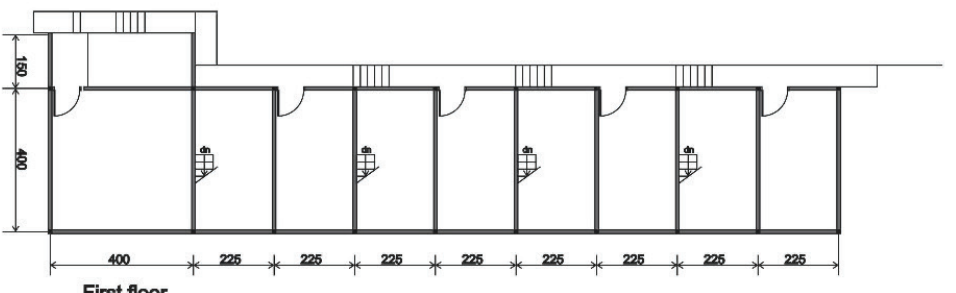

First floor

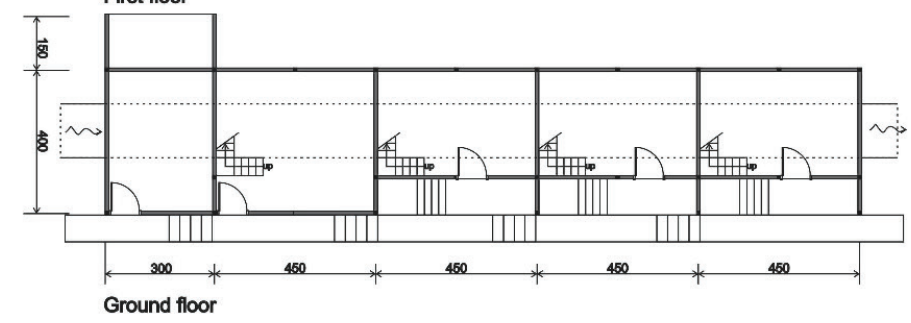

\section{(1)}

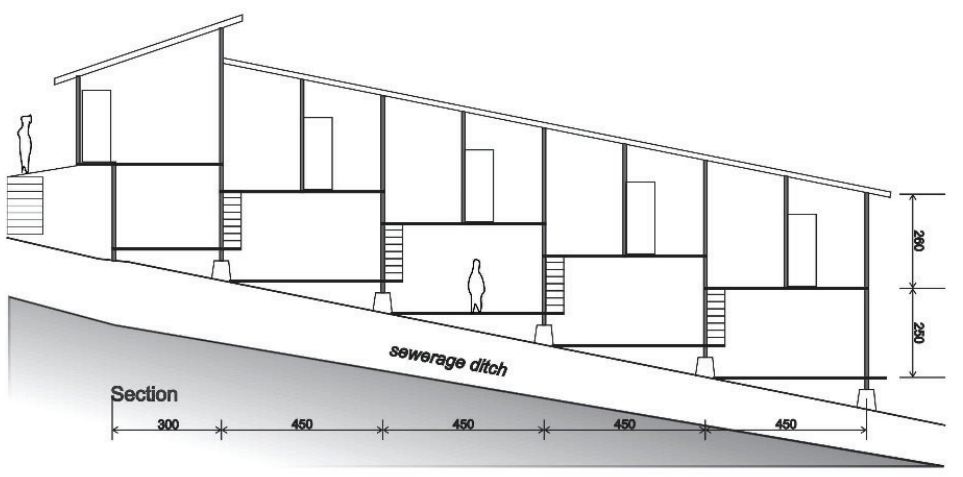

Figure 6. Pictures and drawing of the main flats A in 2018

under the river delivers earthquake wave more intensively rather than other places, a short-distance and shallow hypocenter with the high-frequency tectonic wave will easily affect the building near the river particularly the heavyrigid structure such as concrete and brick houses (Idham, 2014). Brick and other heavyweight materials are not suggested to be utilized in that natural condition.

In term of architectural form as found in the brotherhood building, the simple-extended " $\mathrm{A}$ " wooden truss system combined with timber piles has presented the familiar figure of Javanese house, although the system is entirely different. Unlike the traditional house that sit in the ground, the stilt floor is built by wooden frame with planked finish as well as the wall, and the roof is covered by clay roof tiles in wooden rafter and purlin.

The elevated floor which gives a safe place for the user while giving a chance for water to runoff is the first precaution to the disaster vulnerability based on the environment threat. The stilt house is also as a part of the environmental synchronization to gain the air comfort since the humid nature of the soil and the river bank atmosphere. The wooden material which is easy to be constructed, moveable, and lightweight makes the houses are economically affordable, flexible to be removed, and relatively safe from the earthquake. All these considerations proof that they match with the nature and a sustainable design in architecture as well as aim for the disaster risk preventions.

\subsection{The dwellings and the actual Code settlement in Yogyakarta}

Kampung Code which is recently occupied by 79 households with 344 inhabitants, almost five times from the initial population, is overcrowded. Though the site was expanded to the water stream by adding a forwarded retaining wall and filled with the sediment from the river, the settlement only left a narrow passage on the edge of the bank. More than 45 houses as the existing and additional buildings which were added lately are scattered each other left no open space on the site touching straightly the stream (Figure 7). Most of the new houses are developed in two floors without stilt and constructed by permanent materials such as brick wall and reinforced concrete with the orientation is still facing the river. Mosque and kindergarten have been built as the additional public facilities in the lower bank by increasing the land level with a concrete frame structure.

From the ten main buildings built by Mangunwijaya; the two main flats, the public hall (brotherhood), the central house, and the youth hall remain while the others in southern part are either changed by the people or destructed by the flood in 2011 particularly in the lower parts. One of the collapsed building was rebuilt after by a donor with concrete structure and has given back to the community as a library (Figure $8 \mathrm{a}$ ). The two main flats are still standing and functioned as before except the user is almost doubled compared to 90's occupation. In each 


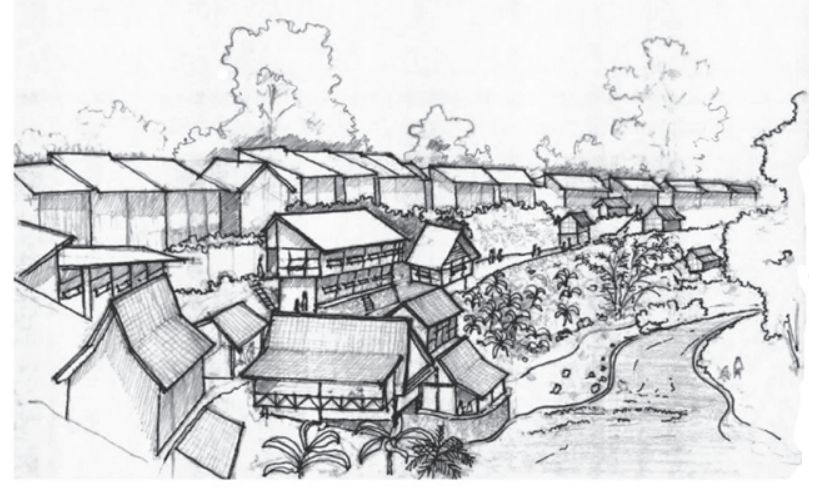

a)

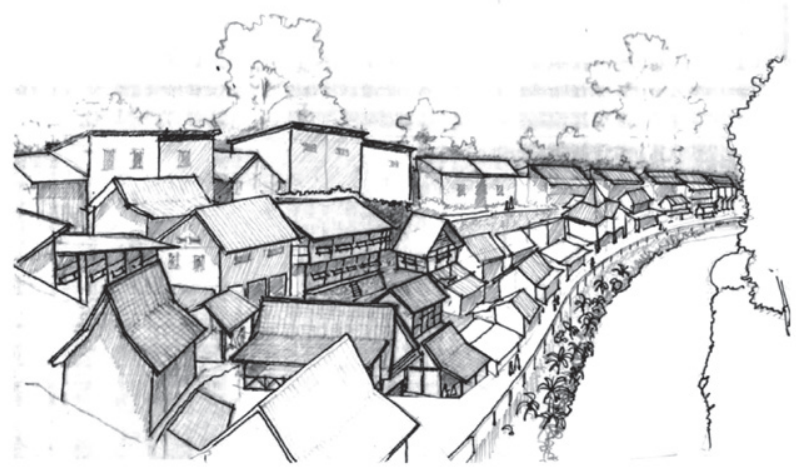

b)

Figure 7. Kampung Code settlement (a) 1991 and (b) 2018 (the 1991 picture was redrawn and optimized from (Al-Radi, 1992))

of those tiny rooms, a family is staying mostly by a family with 3 to 4 persons. Three families shared the central house, and some boys only inhabited the youth hall but mostly in late night and morning time since in daytime to nighttime they are working outside. The brotherhood hall, which was used to watch public television, is left empty and only utilized for gathering and playing. Most of the survived buildings are in decent condition and serve functions suitably.

The people have an agreement between themselves not to remove nor to replace the buildings to preserve Mangunwijaya' works, but in the same time still free to build a new one. Since it stands upon the government land (the Sultan Ground), nobody could state the ownership but free to use the land including the houses with an obligation to maintain the dwellings by some contributions. In term of dwelling existence and social sustainability, the usage arrangement was found effective but at the same time as triggered outsiders to move inside, particularly the relatives of the people. Although most of them are aware that they are living in such illegal housing, the government's "approval" by supporting them with many programs for the poor including regularly delivering food stocks and cash has positioned the people's feeling as in a "comfort zone." Moreover, the floods were felt only less affect them at least for the moment. For the last 25 years, thinking and willing to move out from the bank is even hardly found among the people except whom found a better job and family (married) outside.

Though now the government seems has acknowledged the settlement and has given supports by some improvement programs, some problems remain. Increasing dwelling population in the bank has made the overcapacity settlement as the densest and the most overwhelming neighborhood in the city. Fire exposure is very high since every building touch each other with flammable roof part and unreachable by a firefighter. Emergency pathway also inadequate with the very narrow and stepped alley which making evacuation is in hindrance. Furthermore, the river line does not act as city's open space that providing green belt as buffering zone in critical times such as in case of flood and volcanic overflows. The dense building in the bank has contributed to the outflowing level of the city drainage, and a hundred houses were periodically swept away which make it as the most dangerous settlement in the city.

Another consideration is addressing the upper dwelling line used as garages on the primary street side which also has safety issues. Those informal tire's workshops are mostly built before the Mangunwijaya's settlement and also stand up on the state-owned land although "formalized" by permission and some retributions by the municipality. The buildings are mostly similar to the houses behind except for the newly constructed in the southern edge of the bank which is using more rigid reinforcedconcrete structure. Since the space behind on the bank was still available, the later garages were built with extension to the river with very long-deep RC columns down to the bottom. One of them even completed with cantilever structure which seems too dangerous related to earthquake vulnerability. Unfortunately, some of the dwellings just rested under those new buildings on the bank's side making a more worrying condition of the settlement (see Figure 8b).

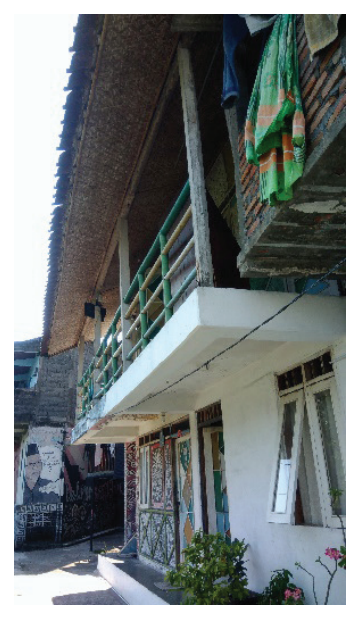

a)

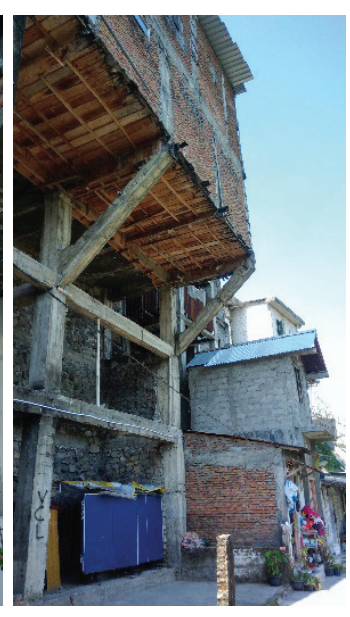

b)
Figure 8. The reconstructed library (a), and (b) the cantilevered garage in 2018 
Instead of following Mangunwijaya dwellings, both in the Kampung Code and other sides of the bank, the people were massively building their houses according to the contemporary housing techniques which are less appropriate for the case. Non-stilted brick-wall houses were constructed side by side leaving very narrow space in between, only allowing people and water to hardly pass through. In case of the lower bank dwellings, this non passable houses (non-stilted house) also block the flows when the river is spilling over causing the stream slow-down, increase-up the flood, and even float-off the houses. Furthermore, when earthquake sways from near hypocenter just like the 2016 earthquake in Opak and Gajahwong River which destroyed a thousand buildings in south-eastern part of Yogyakarta, hundreds of the houses in Code settlements will have the similar possibility. In these "back-to-conventional" riverbank houses, the building vulnerability is very high from natural disaster both flood and earthquake.

\section{Conclusions}

As a well-educated humanitarian architect, Mangunwijaya considered all aspects related to the settlement condition in Code riverbank. His main intention was to solve the social issue in the settlement, but at the same time, he tried to overcome the risk of natural environment without putting himself opposite to the law. His concepts on the project were aim for resolving interconnected problems which are:

- The Code riverbank dwelling with self-help program proposal was initially to determine very critical condition which needs the immediate answer for the worsening humanity and settlement related to the degenerating social environment, the increasing vulnerability on natural disasters, and the continuing unsolved disputes. Mangunwijaya was fully aware that a building residing on the riverbank is dangerous and illegal, he only needs some time to lead the people to be humanized. For this reason, buildings were constructed in semi-permanent but still offer the proper answer to the problems.

- The architecture is a manifestation of the contextual structure which was utilized as the tool to remedy the social and environmental problems by the appropriate dwelling concepts with involving the people, reconstructing and developing more appropriate habits, and protecting the inhabitants from the natural environment risks. The architecture was also utilized as a political tool for influencing the authority to consider on the people rather than the physical environment only as well as to have the more extended time needed to postpone the eviction. All these purposes were accomplished for realizing social order, reducing disaster risks, and minimizing the clashes between the authority and the people.

- Unfortunately, despite the fact that Mangunwijaya was successful on the dwelling concepts proven above, the rest development on the bank's settlement have not directed in the same way. The fail was seems related to "architecture-difficulty" of the different technique used in the construction. The design solving that was considered more in physical results rather than in social philosophy has been functioned immediately but has not easy to be followed directly. Without involvement from other parties especially the government, the people understanding and capability in architectural techniques seems to need a longer time to apply the new technical approaches.

From these results, the positive of the Mangunwijaya's project seems only be seen as a spotted case rather than a pilot project that should be followed by the other riverbanks' dwelling construction afterward. When the different approaches have failed, the authority should take a proper action immediately based on these facts. Otherwise, continuing degradation and the cyclical problem of the settlement and the surrounding environment could not be avoided.

\section{References}

Al-Radi, A. (1992). Kampung Kali Cho-de Yogyakarta. In A. Khan (Ed.), Technical review summary. Retrieved from https://www.archnet.org/sites/752/publications/933

Amalia, R. (2013). Perkembangan Kampung Code sebagai prototipe berkelanjutan membacaruang. Retrieved from https:// www.membacaruang.com/perkembangan-kampung-codesebagai-prototipe-berkelanjutan/

Ayodiya, N. R. P. (2014). Model Kebijakan Permukiman Kampung Code Utara di Tepi Sungai Code. Jurnal Pembangunan Wilayah dan Kota, 10(1), 22-32. https://doi.org/10.14710/pwk.v10i1.7630

Cahyadi, R. (2007). Politik ekologi bantaran Sungai. Universitas Indonesia.

Fabusuyi, T. (2017). Is crime a real estate problem? A case study of the neighborhood of East Liberty, Pittsburgh, Pennsylvania. European Journal of Operational Research, 268, 10501061. https://doi.org/10.1016/j.ejor.2017.12.003

Fahey, C. (2017). Urban or moral decay? The case of twentieth century Detroit. Journal of Architecture and Urbanism, 41(3), 170-183. https://doi.org/10.3846/20297955.2017.1301292

FEMA. (2014). Elevating your house. In FEMA P-312: homeowner's guide to retrofitting (3rd ed.). FEMA. Retrieved from https://www.fema.gov/pdf/rebuild/mat/sec5.pdf

Friesen, J., Taubenböck, H., Wurm, M., \& Pelz, P. F. (2018). The similar size of slums. Habitat International, 73, 79-88. https://doi.org/10.1016/j.habitatint.2018.02.002

Haryadi, T. (2014). Kampung Code Yogyakarta, Gambaran Kehidupan Masyarakat Miskin di Kota. Retrieved from https://www.gudangalamat.com/2015/08/kampung-codeyogyakarta-gambaran-kehidupan-masyarakat-miskin-dikota.html

Hutama, I. A. W. (2016). Exploring the sense of place of an urban Kampung. Retrieved from https://www.webapps.itc.utwente. nl/librarywww/papers_2016/msc/upm/hutama.pdf

Idham, N. C. (2014). Prinsip-prinsip desain arsitektur Tahan Gempa (1st ed.). Yogyakarta: Penerbit Andi.

Istanto, F. H. (1999). Arsitektur "Guna Dan Citra" Sang Romo Mangun, in memoriam: Yusuf Bilyarta Mangunwijaya $6 \mathrm{Mei}$ 
1929 - 10 Februari 1999. Dimensi Teknik Arsitektur, 27(2), 40-47. Retrieved from https://www.puslit.petra.ac.id/journals/architecture/

Kresna. (2014). Pemukiman Kali Code dimulai dari RT 127a. Retrieved from https://www.merdeka.com/peristiwa/pemukiman-kali-code-dimulai-dari-rt-127a.html

Kumorotomo, W., Darwin, M., \& Faturochman, M. A. (1995). The implementation of slum and squatter improvement programs in the river basins of Yogyakarta. Populasi, 6(2). Retrieved from https://www.fatur.staff.ugm.ac.id/file/JURNAL Populasi, 06\%282\%29, 1995.pdf

Lupiyanto, R. (2010). Merancang Kampung Hijau di Tepian Sungai Kota: Kasus Tegalpanggung Yogyakarta. In Buletin Penataan Ruang. Retrieved from https://www.tataruang.atrbpn.go.id/Bulletin/upload/data_artikel/Merancang Kampung Hijau di Tepian Sungai Kota.pdf

Mangunwijaya, Y. (1988). Wastu Citra. Jakarta: Gramedia Pustaka Utama.

Maryono, A. (2009). A study of stream buffer width (case study of rivers in Daerah Istimewa Yogyakarta province). Dinamika TEKNIK SIPIL, 9(1), 56-66. Retrieved from https://www.publikasiilmiah.ums.ac.id/xmlui/bitstreamhandle/11617/230/_9_ Agus Maryono-UGM _ok_.pdf?sequence $=1$

Miller, M. A., \& Douglass, M. (2016). Introduction: decentralising disaster governance in urbanising Asia. Habitat International, 52, 1-4. https://doi.org/10.1016/j.habitatint.2015.08.028

Minnery, J., Argo, T., Winarso, H., Hau, D., Veneracion, C. C., Forbes, D., \& Childs, I. (2013). Slum upgrading and urban governance: Case studies in three South East Asian cities. Habitat International, 39, 162-169.

https://doi.org/10.1016/j.habitatint.2012.12.002

Murty, C. (n.d.). Why are open-ground storey buildings vulnerable in Earthquakes? Retrieved from https://www.bmtpc.org

Nisbett, M. (2017). Empowering the empowered? Slum tourism and the depoliticization of poverty. Geoforum, 85, 37-45. https://doi.org/10.1016/j.geoforum.2017.07.007

Pratama, R. P. Y., Rachmawati, R., \& Kunci, K. (2016). Analisis pemanfaatan dan keberadaan rusunawa di bantaran Kali Code Kota Yogyakarta. Jurnal Bumi Indonesia, 5(2). Retrieved from https://www.lib.geo.ugm.ac.id/ojs/index.php/jbi/article/ viewFile/712/685

Radja, A. M. (2011). 1.191 Rumah di bantaran Code tergenang ANTARA news. Retrieved from https://www.antaranews. com/berita/250626/1191-rumah-di-bantaran-code-tergenang

Ragheb, G., El-Shimy, H., \& Ragheb, A. (2016). Land for poor: towards sustainable master plan for sensitive redevelopment of slums. Procedia - Social and Behavioral Sciences, 216, 417427. https://doi.org/10.1016/j.sbspro.2015.12.056
Ramdhon, A. (2018). Kali Code: Dinamika Kampung Kota \#1. Retrieved from https://www.kampungnesia.org/berita-kalicode--dinamika-kampung-kota-1.html

Redmond, L., \& Desroches, R. (2012). Timber stilt homes. Retrieved from https://www.world-housing.net/WHEReports/ wh100190.pdf

Rolnik, R. (2014). Special rapporteur on adequate housing on her mission to Indonesia. Retrieved from https://www.ohchr.org/ EN/HRBodies/HRC/RegularSessions/Session25/Documents/ A-HRC-25-54-Add1_ch.doc

Sagita, A. F., \& Widiyanto, W. (2012). Penilaian tingkat bahaya lahar hujan di Sungai Code. Jurnal Bumi Indonesia, 1(3), 252260. Retrieved from https://www.lib.geo.ugm.ac.id/ojs/index. php/jbi/article/view/91/89

Sastrawati, I. (2009). The characteristics of the self-support stilt-houses towards the disaster potentiality at the Cambaya Coastal Area, Makassar. DIMENSI (Journal of Architecture and Built Environment), 37(1), 33-40. Retrieved from https://citeseerx.ist.psu.edu/ viewdoc/download?doi=10.1.1.907.2870\&rep=rep1\&type=pdf

Seftyono, C. (2012). Dilema implementasi kebijakan pembangunan bantaran Kali Code-Yogyakarta. Gadjah Mada University. Retrieved from https://www.osf.io/wvkf5/download/ ?format $=\mathrm{pdf}$

Setyaningrum, P., \& Giyarsih, S. R. (2012). Identifikasi tingkat kerentanan sosial ekonomi penduduk bantaran Sungai Code Kota Yogyakarta terhadap bencana lahar Merapi. Jurnal Bumi Indonesia, 1(3). Retrieved from https://www.lib.geo.ugm. ac.id/ojs/index.php/jbi/article/view/92/90

Silas, J. (1992). Kampong Kali Cho-de Yogyakarta. In Technical review, local report. Indonesia.

Sudaryatmo. (2016). Mencermati masalah rumah susun. Yayasan Lembaga Konsumen Indonesia. Retrieved from https://www. ylki.or.id/2016/05/mencermati-masalah-rumah-susun/

Sulistiyono, B. (2011). Prediksi Tinggi Genangan Banjir Kali Code di Kota Yogyakarta Pasca Erupsi Merapi Tahun 2010. In Seminar Nasional Pengembangan Kawasan Merapi: Aspek Kebencanaan dan Pengembangan Masyarakat Pasca Bencana (pp. 89-102). Yogyakarta: Universitas Islam Indonesia.

UN-Habitat. (2016). Urbanization and development: emerging futures (I). Nairobi: United Nations Human Settlements Programme (UN-Habitat). Retrieved from https://www.unhabitat.org

van Voorst, R. (2016). Formal and informal flood governance in Jakarta, Indonesia. Habitat International, 52, 5-10. https://doi.org/10.1016/j.habitatint.2015.08.023

Widodo, J. (2012). Urban environment and human behaviour: learning from history and local wisdom. Procedia - Social and Behavioral Sciences, 42, 6-11. https://doi.org/10.1016/j.habitatint.2015.08.023 